Vol. 11 (1): 63-72 (2021)

\title{
ASSESSMENT OF PHYSICOCHEMICAL WATER QUALITY OF BOUGARA DAM-TIARET, ALGERIA
}

\author{
Leila Soudani $^{1 *}$, Meriem Chafaa ${ }^{1}$, Koula Doukani $^{1}$, Moulkheir Selmani $^{1}$, Saida Djemil ${ }^{1}$ \\ ${ }^{1 *}$ Faculty of Nature and Life Sciences, University of Tiaret, Po. Box78 Zaaroura, Tiaret, Algeria; \\ "Corresponding Author Leila Soudani, e-mail: soudani_leila@outlook.fr;
}

Received November 2020; Accepted December 2020; Published January 2021;

DOI: https://doi.org/10.31407/ijees11.109

\begin{abstract}
The present study aimed at assessing water physicochemical quality of Bougara Dam (Algeria). Water samples were collected in 2019 from different locations within the dam's reservoir for a period of three months (from Mars to May). Several physicochemical parameters ( $\mathrm{pH}$, temperature, electrical conductivity (EC), dissolved oxygen (DO), dry residuals, oxidizable matter $(\mathrm{OM})$, nitrate $\left(\mathrm{NO}_{3}^{-}\right)$, ammoniacal nitrogen $\left(\mathrm{NH}_{4}{ }^{+}\right)$, chloride $\left(\mathrm{Cl}^{-}\right)$, phosphates $\left(\mathrm{PO}_{4}{ }^{3-}\right)$, biological oxygen demand (BOD5) and chemical oxygen demand (COD)) were measured. The result of this research showed that mean values of studied parameters, except phosphates and ammoniacal nitrogen concentrations were within the permissible limit of standards established by the National Agency for Hydraulic Resources (ANRH) and Algerian standards for surface water. These findings constitute a basis for monitoring the physicochemical quality of water in the study area.
\end{abstract}

Keywords: Physico-chemical parameters, Bougara Dam, Tiaret, Water quality. 